\title{
The Efficacy of Chitosan Toothpaste Based White Shrimp (Litopenaeus Vannamei) to Decrease Streptococcus Mutans Colonies in Children with Early Childhood Caries
}

\author{
Yunita Feby Ramadhany $^{1}$, Harun Achmad ${ }^{2 *}$, Putri Khairunnisa ${ }^{1}$, Mardiana ${ }^{1}$ \\ ${ }^{1}$ Faculty of Dentistry, Universitas Hasanuddin, Makassar 90245, Indonesia \\ ${ }^{2}$ Department of Pedodontic, Faculty of Dentistry, Universitas Hasanuddin, Makassar 90245, \\ Indonesia \\ *Email: harunachmader@gmail.com
}

\begin{abstract}
Caries are common in early childhood. The prevalence of early childhood caries according to the American Academy of Pediatric Dentistry is $57.7 \%$. One of the causes is Streptococcus mutans bacteria. The most effective method to prevent plaque accumulation is to brush the teeth with toothpaste. Chitosan is a natural biopolymer that is safe to use as an antibacterial and can be combined with toothpaste for children with early childhood caries. The objective of this study is to determine the effectiveness of chitosan from white shrimp (Litopenaeus vannamei) as toothpaste to reduce S. mutans in early childhood caries. The results of a paired t-test using SPSS ver. 22.0 for Windows showed a significant decrease in the number of colonies of S. mutans from before to after brushing with $5 \%$ chitosan toothpaste. The number of bacterial colonies pretest was $120.4 \mathrm{CFU}$ and that post-test was 11.4 CFU $(p<0.05)$. Chitosan toothpaste $5 \%$ was effective in decreasing the number of colonies of S. mutans in cases of early childhood caries.
\end{abstract}

Keywords: chitosan, white shrimp, toothpaste, Streptococcus mutans

\section{Introduction}

The most common plaque-mediated disease in children is dental caries, which is also one of the most common childhood diseases [1]. The first experience with dental caries in infants and children $<5$ years old is defined as early childhood caries (ECC). ECC can interfere with growth and development of the child, disturb phonetics and articulation, and eventually cause low self-esteem. ECC is a significant problem in developing countries because it is worsened by low social economic status and malnutrition [2]. According to American Academy of Pediatric Dentistry, the global prevalence of ECC in children aged $12-36$ months is $57.7 \%$. The prevalence in Indonesia, is $90 \%$ of the childhood population $[3,4]$.

ECC is multi-factorial disease resulting from the interaction among the host, diet, and microflora on the tooth surface over a period of time, which leads to de-mineralization of hard tissues [5]. The most implicated bacteria in dental caries etiology is Streptococcus mutans for initiation and Lactobacillus acidophilus for progression of caries [6]. S. mutans is an acidogenic bacteria that plays a role as trigger for ECC. 
Sucrose and carbohydrates that contain milk are fermented by S. mutans to form an acidic environment, causing demineralization of the enamel [7-9].

Daily use of an efficient anti-plaque compound, especially a form formulated into toothpaste, can be very beneficial for plaque control, as it suppresses the growth of bacteria, such as S. mutans. [7,10]. Some groups of toothpaste antibacterial compounds, such as phenol, hexetidine, fluoride, and chlorhexidine, have been studied thus far [11]. However, these antibacterial agents have limited use in children with hypersensitivity or allergies. Chitosan has received special attention as a natural biopolymer material because it is non-chemical and natural and has long been used in traditional medicine. Thus, chitosan is a promising antibacterial agent to add to toothpaste [12].

According to Kim, the natural amino-polysaccharides in chitosan have the molecular formula $\mathrm{C} 8 \mathrm{H} 12 \mathrm{NO} 5$ with high levels of $\mathrm{C}, \mathrm{H}, \mathrm{N}$, and $\mathrm{O}$, respectively of $47 \%$, $6 \%, 7 \%$, and $40 \%$ [12]. The main source of chitosan is from the exoskeletons of marine crustaceans, such as shrimp, crabs, and lobsters. The shrimp is a fisheries sector commodity, with high economic value. One type of shrimp that is widely cultivated for export is white shrimp (Litopenaeus vannamei). Indonesian shrimp waste reaches 298,642.25 tons every year [13].

According to research conducted by Akbar, chitosan is an antibacterial agent that degrades bacterial cell walls [10]. Visveswaraiah demonstrated that chitosan inhibits hydroxyapatite acid, which is highly reactive with cariogenic foods [14]. Arnaud showed that the anticariogenic properties of chitosan can act as a mechanical barrier to the enamel [15].

The basis of this study was to test the efficacy of the antibacterial properties of chitosan added to a toothpaste that has the capability of remineralization. Thus, it could be a potential antibacterial agent for children with ECC. We prepared a toothpaste combined with chitosan-based white shrimp (L. vannamei) waste. However, until now, there is no research on the cariostatic effects of toothpaste combined with chitosan. Therefore, we were interested in conducting a study about the efficacy of chitosan toothpaste based white shrimp (L. vannamei) to decrease the number of S. mutans colonies in children with ECC.

\section{Materials and Methods}

Healthy kindergarten students who volunteered in the age range of 36-60 months, and who experienced ECC with at least four caries were recruited as the sample to obtain S. mutans. Other inclusion criteria were: brushed teeth regularly, no periodontal disease, and not taking drugs. In total, 30 subjects participated in the quasi experimental study with pretest, post-test, and control groups. The samples were divided into three toothpaste (TP) groups $(\mathrm{n}=10)$ : (G1) placebo-TP, $2.5 \%$ chitosan$\mathrm{TP}$, and 5\% chitosan-TP. All volunteers provided informed consent to donate a bacterial sample, with approval of the Medical Ethics Committee at Hasanuddin University, Makassar (no: 8/ H04.8.4.5.31/PP36-KOMETIK/2017 and registration no. UH17010015), Indonesia. This research was conducted at TK Cipta Mandiri Makassar, Biochemistry Laboratory Faculty of Mathematics Sciences and Nature, Oral Laboratory Biology Faculty of Dentistry, Hasanuddin University during January 220, 2017. 
This research begins with the preparation of the chitosan from white shrimp (L. vannamei) waste. White shrimp skin was washed with water. Next, shrimp shells were dried in an oven at $80^{\circ} \mathrm{C}$ and macerated using a dry blender. Next, the chitin was isolated in several stages. The first stage was demineralization by immersing the shrimp skin in $3 \% \mathrm{HCl}$ solution. The second stage was deproteinization by immersing the shrimp skin in $4 \% \mathrm{NaOH}$ solution. Then, the shrimp skin was soaked in $60 \% \mathrm{NaOH}$ solution for deacetylation. After that, the chitosan was dried at $65^{\circ} \mathrm{C}$. A $0.1 \mathrm{~g}$ portion of chitosan was sprayed with nihydrin solution and allowed to stand for $5 \mathrm{~min}$. The chitosan was processed in the laboratory of Biochemistry Faculty of Mathematics and Natural Sciences of Hasanuddin University.

The $2.5 \%$ and $5 \%$ chitosan TPs made from white shrimp (Litopenaeus vannamei) were prepared by making the first mixture: $1.2 \mathrm{ml}$ anise oil, $0.1 \mathrm{~g}$ menthol crystals, $1.0 \mathrm{ml}$ perme oil, and leather chitosan powder were mixed with a mortar and pestle until homogeneous. Then, $13 \mathrm{~g}$ of magnesium carbonate and $15 \mathrm{~g}$ of calcium carbonate were stirred with a mortar and pestle until the paste was homogeneous. Then, $3 \mathrm{ml}$ glycerin, $14.2 \mathrm{ml}$ distilled water, 4 g polyethylene glycol, $1.5 \mathrm{ml}$ triethanolamine, and $1.0 \mathrm{ml}$ oleic acid was stirred with a mortar and pestle until the paste was homogeneous. The three mixtures were mixed together and stirred evenly into a fine paste that was ivory white. The paste was put in a tube.

All subjects brushed their teeth in the same way before sampling to minimize confounding variables. The S. mutans was sampled using a swab. Then, the bacterial samples were placed in $0.9 \% \mathrm{NaCl}$ deposited in 60 vials. After brushing their teeth, the child was instructed not to eat or drink for $5 \mathrm{~min}$. Then, the sample was taken after brushing and stored in $0.9 \% \mathrm{NaCl}$ solution.

Then, a $10-3$ dilution was performed using the $0.9 \% \mathrm{NaCl}$ solution. Subsequently, a selective medium (TYSB20 (tryptone yeast extract cysteine sucrose Bacitracin 20)) was made to select and identify S. mutans. One $\mathrm{ml}$ of diluted bacteria was poured into a Petri dish, containing $10 \mathrm{ml}$ sterile TYSB20. Once the suspension was homogenized, it was incubated at $37^{\circ} \mathrm{C}$ for 24 hours. After the incubation, a colony count was performed using the colony forming unit $(\mathrm{CFU} / \mathrm{ml})$ method and a colony counter. The data analysis was conducted with SPSS 22.0 for Windows software (SPSS Inc. Chicago, IL, USA). A paired t-test was performed to test the significance of the number of colonies of S. mutans before and after the treatment in each group. A p-value $<0.05$ was considered significant.

\section{Results}

This research achieved a waiver of ethics with number: 8/ H04.8.4.5.31/PP36KOMETIK/2017 and registration number UH17010015 on January 6, 2017. There was a decrease in the number of S. mutans colonies between the pre- and post-tests in both sexes (Table 1). Females had the highest number of S. mutans colonies, with a pretest colony count of $121.84 \mathrm{CFU}$ and a 28.0 CFU post-test. 
Table 1. Comparison of males and females

\begin{tabular}{|c|c|c|}
\hline \multirow{2}{*}{ Gender } & Pre & Post \\
\hline & Mean \pm SD & $\operatorname{Mean} \pm$ SD \\
\hline Male & $120.8824 \pm 6.07127$ & $26.5882 \pm 14.30498$ \\
\hline Female & $121.8462 \pm 6.14880$ & $28.0000 \pm 14.08309$ \\
\hline Total & $121.3000 \pm 6.01808$ & $27.2000 \pm 13.98127$ \\
\hline
\end{tabular}

A decrease in the number of S. mutans colonies was observed from pretest to post-test in both sexes. The highest number of S. mutans colonies was found in female's pretest, with $122.5 \mathrm{CFU}$ and $44.75 \mathrm{CFU}$ on the post-test. The pretest of the $2.5 \%$ chitosan toothpaste group yielded $122.2 \mathrm{CFU}$ and $27.0 \mathrm{CFU}$ post-test. The $5 \%$ chitosan toothpaste group was $120.75 \mathrm{CFU}$ pretest and $12.5 \mathrm{CFU}$ post-test.

The mean number of S. mutans bacterial colonies in the pretest placebo toothpaste group (Fig. 1) was 121.20 CFU and it was 42.9 CFU post-test. The mean difference was $145.399 \mathrm{CFU}$. The mean number of S. mutans colonies pretest in the $2.5 \%$ chitosan toothpaste group was $122.30 \mathrm{CFU}$ and it was 27.3 CFU post-test. The difference in the mean value was $120.208 \mathrm{CFU}$. The mean number of S. mutans bacterial colonies pretest in the $5 \%$ chitosan toothpaste group was 120.40 CFU and it was $11.4 \mathrm{CFU}$ post-test. The difference in the mean values was $318.64 \mathrm{CFU}$ ( $\mathrm{p}<$ $0.05)$.

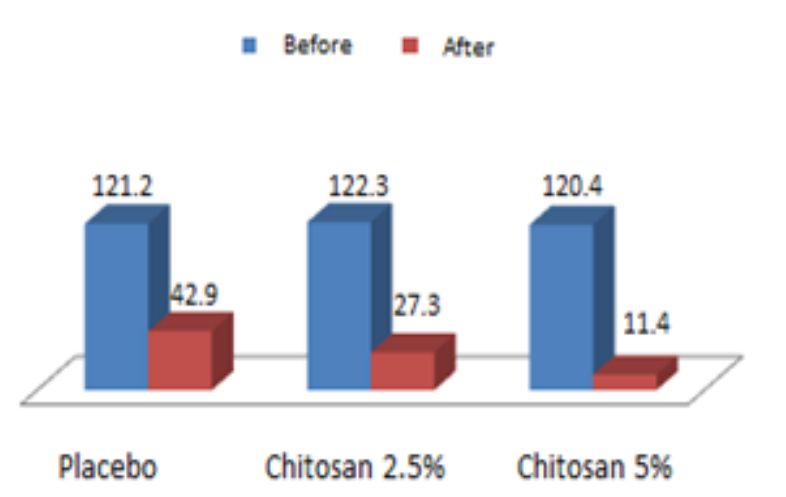

Fig. 1 Diagram of the mean number of Streptococcus mutans colonies before and after brushing with placebo toothpaste, $2.5 \%$ chitosan toothpaste, and $5 \%$ chitosan toothpaste

All toothpaste groups had significant changes. However, the $5 \%$ chitosan toothpaste group has the greatest difference among the placebo toothpaste and $2.5 \%$ chitosan toothpaste groups (Fig. 2). 


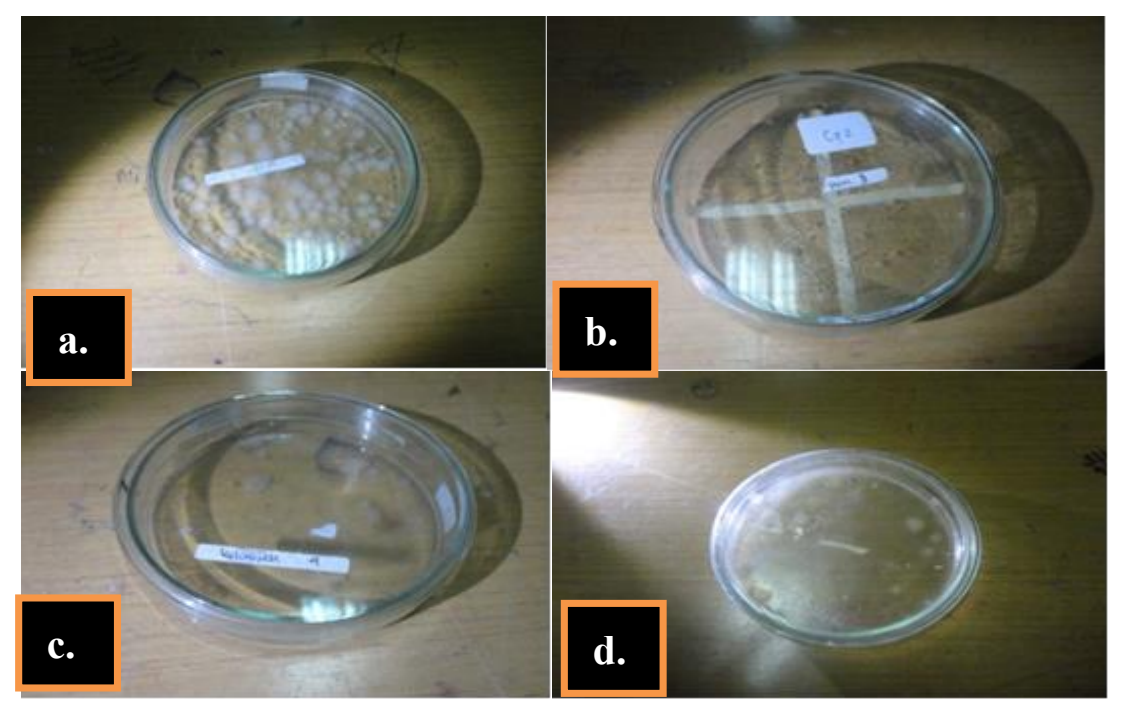

Fig. 2 A Number of colonies of Streptococcus mutans bacteria before brushing teeth; B. placebo toothpaste; C. chitosan toothpaste, 2.5\%; D. chitosan toothpaste, $5 \%$.

\section{Discussion}

Antibacterial effects were seen based on the ability of the toothpastes to kill bacterial colonies measured by counting the decrease in the number of bacterial colonies. The bacterial sample was deposited into a $0.9 \% \mathrm{NaCl}$ as a physiological solution, followed by a 10-3 dilution because it was more effective for reducing the number of bacterial colonies. Previous research streaked S. mutans on blood agar, while in this study S. mutans were cultured on selective TYSB20 medium [16].

This study used $2.5 \%$ and $5 \%$ chitosan concentrations based on research conducted by Visveswaraiah (2016) who reported that $2.5 \%$ and $5 \%$ chitosan is effective and safe for the body [14]. Table 3 shows that the mean number of S. mutans colonies bacteria pretest in the $5 \%$ chitosan toothpaste group was $120.40 \mathrm{CFU}$, whereas it was 11 [4]. CFU post-test $(\mathrm{P}<0.05)$. Chitosan works as an antibacterial agent by combining the ability of toothpaste to inhibit cell division of bacteria. Chitosan interferes with bacterial metabolism by inhibiting bacterial glycolysis. Akbar (2015) reported that chitosan degrades the bacterial cell wall, then destroys the cytoplasmic membrane which causes the nucleus to escape through the bacterial cell wall [10]. 
Table 2. Differences in Mean of Colony Bacteria of Streptococcus mutans by Group of Placebo Toothpaste, $2.5 \%$ Chitosan Toothpaste Before and After Brushing Teeth

\begin{tabular}{|c|c|c|c|c|c|c|}
\hline \multirow{2}{*}{$\begin{array}{c}\text { Tooth pasto } \\
\text { Group }\end{array}$} & Pre & Poct & \multirow{2}{*}{$\mathrm{t}$} & \multirow{2}{*}{ P } & \multirow{2}{*}{\multicolumn{2}{|c|}{$\mathbf{p}$}} \\
\hline & $\mathrm{M}_{21}=\mathrm{SD}$ & $M_{2 n}=S D$ & & & & \\
\hline Placebo & $121.2000 \pm 6.8005$ & $429000 \pm 6.17282$ & 145399 & .000 & $500 \pm 5.35516$ & $27.3000 \pm 4.98999$ \\
\hline \multirow[t]{2}{*}{ 5\% Chiman } & $120.4000 \pm 6.23966$ & $11.4000+3.94968$ & 120268 & .000 & & \\
\hline & & & 318.640 & .000 & & \\
\hline
\end{tabular}

Pavied sarplet-test $p<0$ 05; sigugftart

The results of this study were supported by Ibrahim (2012), who suggested that chitosan interacts with bacteria through the NH3 glucosamine groups and the surface of negatively charged cells [17]. The structural attraction between the bacterial cell wall and chitosan is caused by the bacterial cell wall containing peptidoglycans whose basic main chain structure consists of $\mathrm{N}$ - acetylglucosamine and $\beta$-glycans. The initial interaction between polycationic chitosan and negatively charged cell wall polymers is influenced by electrostatic interactions and citric acid. Consequently, binding of chitosan to the cell wall polymer leads to destabilization and destruction of bacterial membrane function as a protector. Membrane permeability is impaired, leading to inhibited movement of bacterial substances across the membrane.

Cherissa (2016) demonstrated that chitosan has antibacterial properties because it inhibits glucosyltransferase (Gtf) in bacteria [18]. Gtf converts sucrose into two types of glucans, such as water-soluble glucan and insoluble glucan. Water-soluble glucans are also called mutants (1,3 $\alpha$-glucans), whereas insoluble glucans include dextran (1,6 $\alpha$-glucans). Glucans plays a role initiating adhesion of bacteria into a dental plaque. Chitosan may also inhibit the expression of mRNA that induces the formation of cyclooxygenase-2 (prostaglandin-endoperoxidase synthase 2) that plays a role in the mechanisms of inflammation and pain receptors [15].

The results of this study are supported by those reported by Andres (2007) who documented the interaction between chitosan and the outermost bacterial cell membrane, where the concetration effect on antibacterial power is high. Based on the results of other studies, chitosan antibacterial activity decreases with increasing chitosan concentration [19]. In other words, higher inhibition at lower chitosan concentrations, presumably due to the lower viscosity of the solution.

Two antibacterial mechanisms of chitosan against bacteria have been proposed. The first is based on the presence of amine functional groups on chitosan that form bonds with the cell wall of bacteria, resulting in leakage of intracellular constituents, which lyses the bacteria. The second hypothesis states that chitosan begins by destroying bacterial cell walls, engages in intracellular binding, blocks mRNA, and inhibits protein synthesis [19].

According to Setiyani (2015), the antibacterial effect of chitosan is derived from the free amine groups (-NH2) of chitosan, which are protonated into cationic amine groups (-NH3) and can interact with the surface of bacterial cells, which are negatively charged [20]. In addition, the chitosan component eliminates the integrity and function of the membrane so that the cell loses intracellular material. Furthermore, 
cells cannot maintain their homeostatic balance and cell respiration is inhibited [10]. This is also supported by a study by Li, Poon, Li W, Zhu HY, Yeap SH, and Cao $\mathrm{Y}$, et al (2011) which stated that chitosan has antibacterial properties due to interactions between positively charged chitosan molecules and the negatively charged cell membrane [21]. Microbes interfere with the microbial membrane and the breakdown of microbial cell walls and alterations in the permeability of bacterial cells.

Therefore, chitosan toothpaste has a very good antibacterial effect of lowering the number of S. mutans colonies in cases of ECC.

\section{Conclusion}

Chitosan 5\% toothpaste was more effective than chitosan $2.5 \%$ toothpaste and placebo toothpaste. The chitosan 5\% toothpaste had a greater effect on growth of S. mutans in cases of ECC.

\section{References}

1. Thomas A, Thakur SR, Shetty SB. Anti-microbial efficacy of green tea and chlorhexidine mouth rinses against Streptococcus mutans, Lactobacilli spp. and Candida albicans in children with severe early childhood caries: A randomized clinical study. J Indian Soc Pedod Prev Dent. 2016;34(1):65-70.

2. Sugito FS, Djoharnas H, Darwita RR. Relationship between breastfeeding and early childhood caries (ECC) severity of children under three years old in DKI Jakarta. Makara of Health Series. 2008;12(2):87-92.

3. Octiara E, Tamba EA. Hubungan ekonomi keluarga dan pendidikan ibu dengan early childhood caries (ecc) anak usia 12-36 bulan di kecamatan Medan denai. Dentika Dent J. 2012;17(1).

4. [RISKESDAS] Riset Kesehatan Dasar. 2007. Jakarta: Badan Penelitian dan Pengembangan Kesehatan Departemen Kesehatan Republik Indonesia.

5. Zafar S, Harnekar SY, Siddiqi A. Early childhood caries: etiology, clinical considerations, consequences and management. Int Dent SA. 2009;11(4):24-36.

6. Gussy MG, Waters EG, Walsh O, Kilpatrick NM. Early childhood caries: current evidence for aetiology and prevention. J Paediatr Child Health. 2006;42(1 - 2):37-43.

7. Poureslami $\mathrm{H}$. The effects of plant extracts on dental plaque and caries. InContemporary approach to dental caries 2012. InTech.

8. Marsh PD. Dental plaque as a biofilm: the significance of $\mathrm{pH}$ in health and caries. Compendium. 2009 Mar;30(2): CE2.

9. Chetruş V, Ion IR. Dental plaque-classification, formation and identification. Int J Med Dent. 2013;3(2):139-43.

10. Akbar YR, Barqly G, Sulistian A, Elnisa A, Wulan A. Daya antibakteri kitin pada limbah kulit udang terhadap bakteri streptococcus mutans. BIMKGI. 2015 ;3(2):1-2.

11. Resti R, Auerkari EI, Sarwono AT. Pengaruh pasta gigi mengandung xylitol terhadap pertumbuhan Streptococcus mutans serotipe E (in vitro). J Dent Indones. 2013;15(1):1522.

12. Kim SK, editor. Chitin and chitosan derivatives: advances in drug discovery and developments. CRC Press; 2013 Dec 4.

13. Rochima E. Karakterisasi kitin dan kitosan asal limbah rajungan cirebon jawa barat. J Pengolah Has Perikan Indones. 2010;10(1).

14. Visveswaraiah PM, Prasad D. Effect of Water Soluble Carboxymethyl Chitosan and Chitosan Lactate on Enamel Demineralisation-An SEM Study. Res J Pharm Biol Chem Sci. 2016;7(3):427-33. 
15. Arnaud TM, de Barros Neto B, Diniz FB. Chitosan effect on dental enamel de-remineralization: an in vitro evaluation. J Dent. 2010;38(11):848-52.

16. Hasslöf P, Hedberg M, Twetman S, Stecksén-Blicks C. Growth inhibition of oral mutans streptococci and candida by commercial probiotic lactobacilli-an in vitro study. BMC oral health. 2010;10(1):18.

17. Ibrahim B, Suptijah P, Zahid A. Efektivitas kitosan sebagai alternatif antibakteri alami dalam mouthwash. J Pengolah Has Perikan Indones. 2012; 15:124-125.

18. Cherissa CDMD. Review of approaches to caries treatment. Dental Theses (Penn Dental Medicines). 2016. p. 24-27.

19. Andres Y, Giraud L, Gerente C, Le Cloirec P. Antibacterial effects of chitosan powder: mechanisms of action. Environ Technol. 2007;28(12):1357-63.

20. Setiyani R, Maharani DK. Uji aktivitas antibakteri kitosan, ZnO dan komposit kitosan $\mathrm{ZnOSiO} 2$ sebagai agen antibakteri pada kain katun. Prosiding Seminar Nasional Kimia Universitas Negeri Surabaya. Oktober, 2015. C-57.

21. Li P, Poon YF, Li W, Zhu HY, Yeap SH, Cao Y, Qi X, Zhou C, Lamrani M, Beuerman RW, Kang ET. A polycationic antimicrobial and biocompatible hydrogel with microbe membrane suctioning ability. Nat Mater. 2011;10(2):149. 